\title{
The Impact of Emotional Attachment in Volunteer Tourism
}

\author{
Pisey Toch \\ Pusan National University, South Korea
}

\begin{abstract}
Volunteer tourism is recently gaining popularity among young volunteers and some of them are interested in working with children in developing countries. However, in volunteer tourism, studies are rarely focused on emotional attachment between volunteers and children. This study explores how emotional attachment is influent to the context of volunteer tourism and the impact of emotional attachment to behavioral intention and well-being of volunteer tourists. Moreover, this study also makes the discovery about how well-being is impacted to behavioral intention of volunteer tourist which focus on residential child care centers in Cambodia. There is a total of 174 responses of volunteer tourists in the residential child care center in Cambodia. The results suggest that emotional attachment has a significant connection to donation intention and well-being, while well-being has a significant connect in revisit intention and donation intention
\end{abstract}

Keywords: Cambodia, donation intention, emotional attachment, revisit intention, volunteer tourism, well-being.

\section{Introduction}

Tourists have changed their perception of traveling according to generation and globalization. Mass tourism was very popular since the mid-1960s; however, more recently tourists are less satisfied with mass tourism activity (Lo \& Lee, 2011). Similarly, popular or "mass tourism" was not the best practice, and this has changed the focus to alternative types of tourism (Burns \& Holden, 1995). One new form of alternative tourism that has become popular among tourists is "volunteer tourism" (Henderson,1981). Volunteer tourism is gaining popularity so fast among the forms of tourism (Brown \& Morrison, 2003; Harlow \& Pomfret, 2007; McIntosh \& Zahra, 2007).

Volunteer tourism is well known as a sustainable form of tourism with providing much potential benefits (Ooi and Laing, 2010; Wearing, 2004) including local capacity building (Wearing, 2001) or poverty alleviation (Stoddart and Rogerson, 2004). In addition, the volunteer experiences are able to change volunteer tourists' life, which can improve their confidences, knowledge, skills and give them a chance to learn about themselves (Broad, 2003). Volunteering activities are significant in communities as well as social and environment developments with sustainability (Bruyere, \& Rappe, 2007; Stukas, Snyder, \& Clary, 2008).

The concept of emotional attachments can create politically engaged volunteer tourism and also provide useful academic critiques Conran (2011). Conran also mentioned that intimating with host community members is the important factor when volunteer tourists make decision to volunteer rather than travel. Similarly, emotional attachment plays a role in 
influence factor to make the customer's long lasting relationship with brand (Levy \& Hino, 2016). For instance, through emotional attachment among volunteer tourists are capable to be satisfied by and maintain their relationship with the stakeholder. Levy and Hino (2016) also mentioned that emotional values of sympathy, empathy, and love can build differentiation, which has the potential to influence customers' behavioral decisions. Emotional attachment can predict the natural individual's interaction with the stakeholder (Thomson et al., 2005), and is the result of long term relationship (customer and service provide) during the service experience (Phillips \& Baumgartner, 2002).

The motivation of volunteer tourists in the residential care centers are self-interest or altruism (personal or interpersonal). In other words, volunteer tourists expect to help children, again their person experiences or their well-being. However, while they are volunteering some unexpected interact happen such as donating something or revisiting the residential care center. The interaction during volunteer period can make volunteers and children relationship closer and create volunteer tourists' emotional attachment. The closeness or intimacy can be continued with long term processing. For example, volunteers still keep in touch with children and residential care centers staffs or keep provide some helps to children by direct or indirect ways.

With being in process research, some unrespecting behaviors depend on tourists' prosocial behavior. The research on social phenomena sophisticated theories get from vast theory have become visible. Consequently, managing researches contributed by advanced theories are unavoidable in the tourism consumer behaviors in the tourist industry. Particularly, the important requirement for successful performance of volunteer tourism is the continuous behavioral intention of volunteers such as revisit volunteer places and maintain their relationship with stakeholder. Nevertheless, in present study, application to the theories have to establish in tourism study for constant connection.

The present study is aimed to conceptual model which theoretical relationship emotional attachment, well-being, revisit intention and donation intention in volunteer tourism. The last purpose is to examine the relationship between well-being and behavioral intention (revisit intention and donation intention).

\section{Literature Reviews}

\subsection{Emotional Attachment}

Based on attachment theory (Bowlby, 1969/1982), as human being naturally dresses with attachment and caregiving behavioral system in the group of other essential behavioral system such as exploration, sexual mating) since during evolution, becoming emotionally attached to caregivers of parents and giving care of dependent or individuals (infant or family) improved inclusive fitness. Park and MacInnis (2006) claimed that "Emotional attachment is a relationshipbased construct that reflects the emotional bond connecting an individual with a consumption entity (e.g., brand, person, place, or object)" (p. 17). Many researchers have admitted that attachment roles are an important determinant because of attachments related to desirable marketing consequences (Jiménez \& Voss, 2014). The involvement of emotional attachment is not only a strong predictor of word of mouth and behavioral loyalty Vlachos, Theotokis, Pramatari \& Vrechopoulos (2010), It is also interconnected with trust, commitment, and satisfaction (Rempel, Ross, \& Holmes, 2001; Spake, Beatty, Brockman, \& Crutchfield, 2003; Thomson, 2006; Thomson, MacInnis, \& Park, 2005), consumer defections (Liljander \& Strandvik, 1995), disposal choice (Walker, 2006), evaluations of brand extensions (Fedorikhin, Park, \& Thomson, 2008), brand 
loyalty (Thomson, MacInnis, \& Park, 2005), and negatively to unethical behavior (Schmalz \&, 2012).

In tourism researches should concentrate about the political feeling Buda et al. (2014) (p. 102). As consequence, Guiney (2018) studied about emotional labor in the concept of volunteer tourism in residential care centers in Cambodia while few studies have focused on emotion in volunteer tourism literature (Conran, 2011; Cousins, Evans, \& Sadler, 2009). However, the concept of emotional attachment has been used to study the relationship of parents and children (Ladhari, Massa Orth \& Skandrani, 2020) and material possessions, places, brands, and celebrities (Dwivedi et al., 2018; Thomson, 2006). In attachment theory, for children who live in residential care centers are close with caregivers, and can be a protective factors and aid for their overall development (Freud \& Danns, 1951; Rutter \& Maughan, 1997; Wolff \& Fesseha, 1998).

One of the most popular activities in volunteer tourism studies is interaction with the children (Carpenter, 2015). The interactions between health care providers and persons who lives in residential care are really important (Clark 1996; Nay 1998; Keller \& Baker 2000; Burgio et al. 2002). The affection of this communication can help health care providers to estimate the individual needs of residents (Farrell 1993; de Lucio et al. 2000). Moreover, the interaction of two parties can enhance quality of life and well-being for residents (Brannon et al. 1992; Maas et al. 1994; Caris-Verhallen et al. 1999). Volunteer tourist's experiences related to interaction between volunteer tourists and local people (Brown, 2005; Lo \& Lee, 2011; McGehee \& Santos, 2005; McIntosh \& Zahra, 2007).

In the context of orphan volunteer tourism, children are the important role in volunteer tourist's experiences and children caused positive (influence their behavior and characteristic) and negative feeling to volunteer tourists (Proyrungroj, 2017). Tourist's experience can predict the future behavioral intention and volunteer's experience might effect to future volunteering (Doherty, 2009). Similarly, involvement in the past volunteer activities is a principal determinant of future volunteering (Hall, Lasby, Gumulka, \& Tryon, 2006).

Emotional attachment has positive effect to customer satisfaction and behavioral intention (Lee and Park,2019; Shin, Rhee \& Kim,2016). Similarly, plenty of studies mentioned that outcome of satisfaction is behavioral intention (Andreassen \& Lindestad, 1998; Oliver, 1997; Yürük, Akyol, \& Şimşek, 2017). In volunteer tourism context, behavioral intention is defined as continuously being involved with volunteer activities and volunteering member (Blau \& Holladay, 2006). Behavioral intention (eg. revisit intention and intention to donate) has received much attention from volunteer tourism studies (Meng et al., 2020). Donation intention is one of behavioral intention. Cultural system, religion and personal factors are the behavior of the donor (Ranganathan \& Henley, 2008). The behavior of a donor to donate money largely depends upon cultural systems, religion, and a few personal factors (Ranganathan \& Henley, 2008). Some researchers mentioned that demographics also the important role which is influenced charity donation intentions (Lord, 1981; Burgoyne, Young, \& Walker, 2005; Lee \& Chang, 2007). Past behavior can predict about intention to donate money of the donors (Sutton, 1994) and behavioral intention (Bozionelos \& Bennett, 1999). Emotional attachment has power on motivational and behavioral implications, the reason is an individual is strongly attached to a person or object that they are willing to make relationship with (Wan, Lu, Wang, \& Zhao, 2017). In other words, people donate something because they feel attached with organization (Brady et al., 2002). Wan, Lu, Wang, \& Zhao (2017) they revealed that the emotional attachment of content creators in social media has positive effect to intent to donate to content creators in social media.

Each attachment style such as secure attachment, fearful attachment, preoccupied attachment and dismissing attachment, all have positive effects to well-being (Karreman \& Vingerhoets, 2012). they also found out that secure attachment has the strongest positive effect to well- being. 
Davis, Morris and Drake (2016) revealed that attachment anxiety also has positive effect to wellbeing. However, Levy and Hino (2016), studied about the relationship between customers and emotional brand attachment. They revealed that emotional attachment is significant to customer's loyalty and customer's satisfaction.

Wie and Milman (2002) mentioned that activities during vocation peaked tourist's satisfaction and learned that tourists psychological well-being interrelates with each other. Travel satisfaction can cause effect to global subjective well-being (Schimmack \& Wagner, 2008), and traveling indirectly seems to have effects on global subjective well-being (Bergstad et, all., 2011). Likewise, Diener, Lucas and Oishi (2002) stated that subjective well-being is related to life satisfaction. The studies of well-being mostly provide benefits to volunteers rather than volunteer work (Thoits \& Hewitt, 2001).

H1: Emotional attachment has positive effect to revisit intention.

$\mathrm{H} 2$ : Emotional attachment has positive effect to donation intention.

H3: Emotional attachment has positive effect to well-being.

\subsection{Well-being}

In many tourism researches focus on well-being as well as quality of life and life satisfaction (e.g. de Bloom et al., 2010; Dolnicar, Yanamandram, \& Cliff, 2012; Gilbert \& Abdullah, 2004; Hoopes \& Lounsbury, 1989; Neal, Sirgy, \& Uysal, 1999; Neal, Sirgy, \& Uysal, 2004; Neal, Uysal, \& Sirgy, 2007; Pearce, Filep, \& Ross, 2010; Richards, 1999; Sirgy, 2010; Sirgy, Kruger, Lee, \& Yu, 2011, Dagger and Sweeney, 2006; Endres, 1999; Yuan, 2001). Some studies concentrated on well-being contributes to tourism literature (Coghlan, 2015; Doyle et al., 2016; Filep, 2009; Filep and Deery, 2010; Filep et al., 2017; Filo and Coghlan, 2016; Matteucci and Filep, 2017). The conceptualization of quality of life is related to one's life condition and personal satisfaction (Felce \& Perry,1995). Ryff (1989) stated that general well-being is defined as life satisfaction. In other words, Mannell and Klieber (1997) defined the psychological well-being as feeling of enjoyment, happiness or satisfaction. There is a similarity between the concept of customer well-being and customer satisfaction (Kim, Jeon \&Hyun, 2012).

Baker and Crompton (2000) revealed that satisfaction has a positive effect to behavioral intention. Behavioral intention (Baker \& Crompton, 2000; Sparks, 2007) and revisit intention (Li et al., 2010; Um et al., 2006) are both extensively mentioned in tourism literature. Raza, Siddiquei, Awan and Bukhari (2012) found out that customer satisfaction has a more positive relationship with behavioral intention. Moreover, Pratminingsih, Rudatin and Rimenta (2014) stated that satisfaction has a positive effect to revisit intention. Satisfaction level of volunteers positively effect to willingness of volunteer in repeating involvement in the future (Ferreira, Proença \& Rocha, 2016).

Wie and Milman (2002) mentioned that activities during vocation peaked tourist's satisfaction and learned that tourists psychological well-being interrelates with each other. Travel satisfaction can cause effect to global subjective well-being (Schimmack \& Wagner, 2008), and traveling indirectly seems to have effects on global subjective well-being (Bergstad et, all., 2011). Likewise, Diener, Lucas and Oishi (2002) stated that subjective well-being is related to life satisfaction.

The perceive well-being is mirror of customer's positive experience with and impact to revisit intention (Grzeskowiak and Sirgy, 2007; Jones and Sasser, 1995). Similarly, Kim and Hyun (2012) also found out that customer well-being has positive effect to behavioral intention. Due to studies have mentioned above, well-being has power on revisit intention of volunteer, they will visit the place that they volunteered before. In summary, well-being of volunteer tourists is likely to develop positive affection toward behavioral intention, which can lead to positive attitude of revisiting 
residential child care centers.

Hypothesis 4: Well-being has positive effects to revisit intention.

Kim, Lee, and Preis (2020) studied about virtual reality (VR) in tourism context, they found out that subjective well-being is more influenced to behavioral intention than authentic experience. However, charitable giving, reveals something about people's helping behavior which is also including altruism (Batson, 1981). If a man feels empathetic, they would feel the need to help (Eisenberg \& Miller, 1987). In this emotional world, donation often gives heavy influence to emotion among customers and a customer's giving behavior (Dillard \& Peck, 2000).

People who were satisfied with the event will have better intentions to join other events" (Taylor \& Shanka,2008; Hendriks \& Peelen, 2013). The effect of satisfaction can help the studies of alumni donations to universities (Gaier 2005) and members' donations to professional associations (Wang $\&$ Ashcraft, 2014).

Hinrichs et al (2008) studied about effect of blood donation on well-being of blood donors. They found out there are difference between person who has experience and non-experience of donating blood. For those who has experience, they might feel proud or altruism. They suggested that wellbeing is linked with positive and successful donation experience. Due to their study we can assume that well-being can increase volunteer's intention to donate.

Hypothesis 5: Well-being can have positive effect to donation intention.

\subsection{Revisit Intention}

Revisit intention is defined as willing tourists revisiting to the same destination more than once (Fishbein \& Ajzen 1975, Baker \& Crompton 2000, Gronhold et al., 2000). Metin Kazak (2001) stated that there are some factors that can make people to intention to choose their visiting destination such as economic, psychological, media, communication, demographic, and experience (Ankomahet al., 1996; Curt and Lupton 1997; Gitelson and Cromton 1984; Goodall 1988; Mayo and Javis 1981; Um and Crompton 1990, Woodside and Lysonski 1989). Revisit intention is the outcome of tourist satisfaction (Bigne et al 2001). In other words, tourists can revisit that destination again because they had had satisfactory experiences while on their trip or they had something special or psychological emotional attachment to that destination.

Marketing researchers had focused much on the relationship between the customer's loyalty and satisfaction (Anderson and Sullivan 1993; Hallowell 1996; LaBarbera and Mazursky 1983; Newman and Werbel 1973, Oliver 1980, Rust \& Zahorik 1993). Due to this perspective, customer's willingness and intention on purchasing products rely on their satisfaction. Thus in conclusion, when tourists enjoy their experiences, they make an effort to go back to that same destination again in the future (Ross, 1993). Likewise, tourists who have positive opinions on their trip are said to have a higher probability of revisiting their previous destinations (Juaneda, 1996).

\subsection{Donation Intention}

Children are expected to be "poor-but-happy" and to engage intimately with volunteers and visitors to engender tourist satisfaction and encourage sympathy and donations (Guiney, 2018). Volunteer tourism is distinct from traditional donations from a distance, bringing "a giver closer to the afflicted, the poor, the suffering, and the needy, if only for a short time" (Bornstein, 2012, p. 113). Because of this direct contact in orphanage tourism some have even coined these interactions 
"hug-an-orphan" vacations, illustrating how important intimacy is within these experiences (Schimmelpfennig, 2011). Volunteer projects involving children are among the most popular international volunteering projects (Tomazos \& Butler, 2009), with $21 \%$ of gap year volunteer projects directly involving children or young people (Jones, 2004). Despite this, more than a decade later there remains a dearth of literature that interrogates volunteer tourism projects with children.

Orphanage tourism in Cambodia is extremely popular and diverse. It comprises a range of interactions - tours, donations, cultural performances on site or in hotels, and volunteering, especially short term. Although volunteer-sending organizations do operate in the nation, directly contacting local organizations is equally, if not more frequently, practiced. Indeed, for this paper only five volunteers I spoke to had gone through large international sending organizations, while the remaining 31 had contacted local organizations directly (Guiney, 2018). I then outline how commodifying emotion can have significant financial benefits for orphanages, considering how this economic incentive can result in orphanage directors pressuring children to perform particular stereotypes of vulnerability and emotion. (Guiney, 2018).

UNICEF (2011) identifies that children are expected to befriend tourists in these interactions in order to garner donations. Furthermore, a recent news story has outlined the pressure placed upon children to present sad faces and stress their lack of food and dependence on volunteers and visitors, in an attempt to elicit sympathy and donations (Watson, 2014b). Children in orphanages, as with many volunteer tourism forms, are constructed as "poor-but-happy" (Crossley, 2012; Simpson, 2004) and tourists expect children to be happy, despite their situation, which provides a sanitized interaction with poverty and leaves the tourists feeling positive about their experience (Crossley, 2012).

The studies in developing countries are limited to the identification of the role of demographics such as age, gender, and income to influence charity donation intentions (Lord, 1981; Burgoyne, Young, \& Walker, 2005; Lee \& Chang, 2007). Because much of research has focused on identifying the demographics of donors, most studies do not imply a theoretical framework that can help in sketching a complete picture of donation intentions (Greenslade \& White, 2005). researchers have highlighted the role and impact of past behavior in predicting intentions to donate money (Sutton, 1994). The element of past behavior has been acknowledged as a strong predictor of behavioral intentions (Bozionelos \& Bennett, 1999). These researchers believed that past behavior is a much stronger predictor of intentions as compared with attitudes as it predicts socially acceptable behaviors (Lee, Piliavin, \& Call, 1999).

To answer the question, "why do people donate to a charity?" there are several reasons, according to researchers such as attitudes toward charitable organizations, (Webb et al., 2000), altruism, (Piliavin and Chang, 1990), religiosity (Hoge, 1995), involvement (Chiang, 2003), donor characteristics, (Pessemier et al., 1977) and size of request (Reingen, 1978). Tourists who volunteer at orphanages donate something because they want to do something good. Also, most orphanages and child care centers rely on donations from visitors (Hanel, 2017). Nguyen, Hirschler and Murphy (2008) found out that $75 \%$ of high school female blood donors have higher satisfaction male, and satisfaction of donating blood has relationship with intent to return for another donation. 


\section{Methodology}

\subsection{Sample}

This study tests the proposed model on emotional attachment and well-being of volunteers who have experience in residential child care center in Cambodia. The sample was collected from one residential care center called "National Borey Infant and Children" (NBIC) in Phnom Penh, Cambodia. An offline survey was delivered to volunteers who were volunteering in NBIC, and online survey was delivered to volunteers who had already finished their volunteer service and had gone back to their home countries. For the first part of the survey, respondents answered the question: "Have you had any experiences of volunteer tourism in residential child care centers in Cambodia?" For respondents who had answered "Yes", they would be able to move on to the next step of the survey. For respondents who answered "No", they would not be able to continue the study survey anymore.

This survey was conducted from the 13th of November 2019, through the 12th of March, 2020. These surveys were delivered to respondents who were from Europe, USA, Australia, Canada and other countries accept Asia countries. There were in total 314 respondents who answered this survey. Two respondents answered "No", while the useable data was 312, and while 43 respondents used the offline survey, and 271 participants were online respondents.

This study is also aimed to investigate the empirical structure relationship of volunteer tourists' emotional attachment toward behavior intention (donation intentions and revisit intention), and well-being. Moreover, we also investigated the relationship of well-being toward behavior intention of volunteer tourists who volunteer in residential child care centers in Cambodia. All of these items were scored using five-point like-type scales ranking from 1 to $5.1=$ "strongly disagree" and $5=$ strongly agree.

For measuring the theoretical concept in model, the measurement items were adapted from previous studies such as-

-Emotional attachment: measuring with 11 items from Hyun and Kim (2014).

-Well-being: measuring with 4 items from Grzeskowiak and Sirgy (2007), Kim et al. (2012), and Kim and Kim (2017).

- Re-visit intention: measuring with 3 items from Zhang, Wu \& Buhalis (2018) and another 3 items for re-volunteer intentions adopt from (Kim, Park, Kim \& Kim, 2019).

-Donation intention: measuring with 4 items from Ranganathan and Henley (2008).

\subsection{Data Analysis Tools}

In this study were used SPSS 25.0 and AMOS 21.0. In order to fit the purpose of this study, we constructed structural equation model. The significance of $\mathrm{p}$-value was under 0.05 . This study used AMOS to estimate confirmatory factor analysis, correction model, and research model (final model) by using maximum likelihood. The information on the and the fitness values were presented to check the fit of the model. The bootstrapping method was used to examine the indirect effect of emotional attachment to revisit intention and donation intention.

In order to examine the internal consistency of each measurement variable the reliability, we use the Cronbach's alpha coefficient. In case that 0.6 or more than this, it means that is reliable. In addition, if it is 0.8 or more than this reliable is high. 


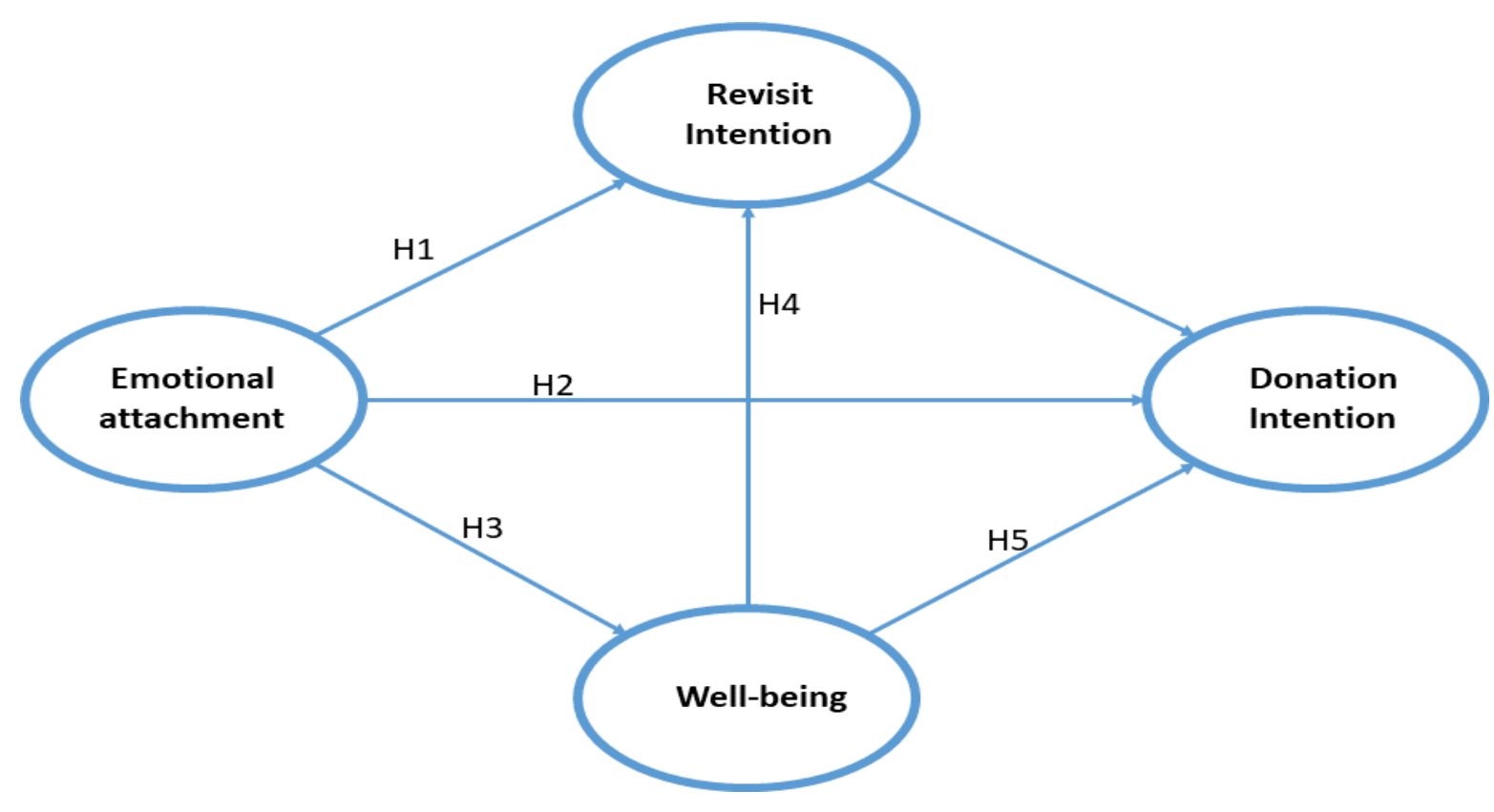

\section{Result}

\subsection{Profile of Respondents}

<Table 1> reveals the demographic profile of volunteer tourists who participated in this study. A total valid sample in this study is 174 , the respondents were obtained from demographic characteristic through analysis process. Female respondents were $154(88.5 \%)$ and male respondents were $20(11.5 \%)$. Age group was divided into 5 such as less than 20 years old $5(2.9 \%)$, from 21-30 years old 162 (93\%), from 31 to 40 years old $6(3.4 \%)$, from $41-50$ years old $0(0 \%)$ and more than 50 years' old $1(0.6 \%)$. Question about marital status, single respondents 142 $(81.6 \%)$, married respondents $31(17.8 \%)$ and divorced respondents $1(0.6 \%)$.

For income question divided into 8 groups, however, only 3 groups have been answered from respondents such as under $\$ 25,000117$ (67.2\%), from \$25,000-\$49,999 40 (23\%) and \$50,000$\$ 74,99917(9.8 \%)$. In the questions of level of education divided into 6 group, but less than high school diploma has no answer from respondent, other 5 groups such as high school diploma 10 (5.7\%), some collect, but no degree 5 (2.9\%), associate's degree 7 (4.0\%), bachelor's degree 135 (77.6\%) and graduate degree $17(9.8 \%)$.

For occupation question divided into 7 groups such as company employee 33 (19.0\%), own business $2(1.1 \%)$, sale/service $2(1.1 \%)$, student $113(64.9 \%)$, homemaker 4 (2.3\%), no job 7 (4.0\%), and other $13(7.5 \%)$. 


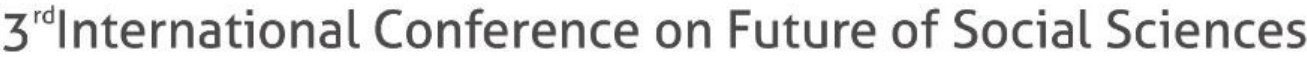

\section{5 - 7 March 2021}

BERLIN, GERMANY

For all respondents from Europe, Canada, North America, central America, and Australia.

\begin{tabular}{|c|c|c|c|}
\hline & Variable & $\mathrm{n}$ & $\%$ \\
\hline \multirow{2}{*}{ Gender } & Male & 20 & $11.5 \%$ \\
\hline & Female & 154 & $88.5 \%$ \\
\hline \multirow{4}{*}{ Age } & less than 20 & 5 & $2.9 \%$ \\
\hline & $21-30$ & 162 & $93.1 \%$ \\
\hline & $31-40$ & 6 & $3.4 \%$ \\
\hline & More than 50 & 1 & $0.6 \%$ \\
\hline \multirow{3}{*}{ Marital statue } & Single & 142 & $81.6 \%$ \\
\hline & Married & 31 & $17.8 \%$ \\
\hline & Divorced & 1 & $0.6 \%$ \\
\hline \multirow{3}{*}{$\begin{array}{l}\text { Income } \\
\text { (USA\$) }\end{array}$} & Under $\$ 25,000$ & 117 & $67.2 \%$ \\
\hline & $\$ 25,000 \sim \$ 49,999$ & 40 & $23.0 \%$ \\
\hline & $\$ 50,000 \sim \$ 74,999$ & 17 & $9.8 \%$ \\
\hline \multirow{5}{*}{ Academy } & High school diploma & 10 & $5.7 \%$ \\
\hline & Some college, but no degree & 5 & $2.9 \%$ \\
\hline & Associate's degree & 7 & $4.0 \%$ \\
\hline & Bachelor's degree & 135 & $77.6 \%$ \\
\hline & Graduate degree & 17 & $9.8 \%$ \\
\hline \multirow{7}{*}{ Occupation } & Company employee & 33 & $19.0 \%$ \\
\hline & Own business & 2 & $1.1 \%$ \\
\hline & Sales/service & 2 & $1.1 \%$ \\
\hline & Student & 113 & $64.9 \%$ \\
\hline & Homemaker & 4 & $2.3 \%$ \\
\hline & No job & 7 & $4.0 \%$ \\
\hline & Other & 13 & $7.5 \%$ \\
\hline
\end{tabular}

\subsection{Measurement Model}

There is two-step to analyze structural equation modeling (SEM) recommended from Anderson and Gerbing (1988). In order to test the hypothesized relationships, confirmatory factor analysis which validates the measurement model. The measurement model was included the acceptable fit 


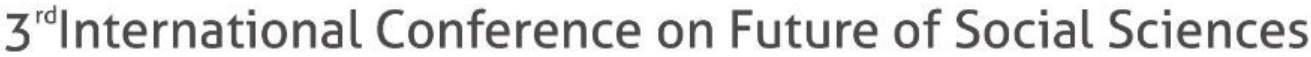

data (goodness-of-fit statistics for the measurement model CMIN=195.438, DF=98, CMIN/DF= $1.994, \mathrm{p}<.001$, comparative fit index $(\mathrm{CFI})=.909$, incremental fit index $(\mathrm{IFI})=0.911$, TuckerLewis index $(\mathrm{TLI})=0.889$, AGFI $=0.840$, goodness-of-fit index $(\mathrm{GFI})=0.885$, root mean square error of approximation (RMSEA) $=.076$.

Further, it was revealed that emotional attachment construct by comparing a second-order factorial model with first-order factorial model (Anderson \& Gerbing, 1988; Casaló et al., 2011). The result shows that model fit with the first-order factorial model $\mathrm{CMIN}=195.455, \mathrm{DF}=99$, $\mathrm{CMIN} / \mathrm{DF}=1.974, \mathrm{p}<.001, \mathrm{CFI}=.91, \mathrm{IFI}=0.912, \mathrm{TLI}=0.912, \mathrm{AGFI}=0.841, \mathrm{GFI}=0.885$, RMSEA $=.075$.

Table 2: shows about scale items for each construct, AVE value, and composite reliability (CR). According to observational variable and construct are validity and reliability. Additionally, the proof of convergent validity was applied, in factor loading for items which ranged from 0.375 to 0.898 , so it revealed significant ( $\mathrm{p}<.01)$; and one more the value of the average variance extracted (AVE) for all latent construct exceeding the threshold of .50 (Fornell \& Larcker, 1981). In table 2 also reveals the AVE value and composite reliable. Proof of internal reliability was shown of each latent construct with CR ranged from .834 to .910 exceeded the threshold .70 (Nunnally \& Bernstein, 1994). The discriminant validity of all construct was estimated. The discriminant validity of each construct was estimated, and was confirmed by AVE value higher than he squared correlation coefficients (Fornell \& Larcker,1981). They recommended that the discriminant validity was assessed by comparing the AVE value of each construct and squared correction between all pairs of latent construct. In table 1 squared correction between a pair of constructs were lower than AVE value of each constructs. Due to this case Bagozzi and Yi (1988) recommended, discriminant validity between pairs needed to be reexamined. 


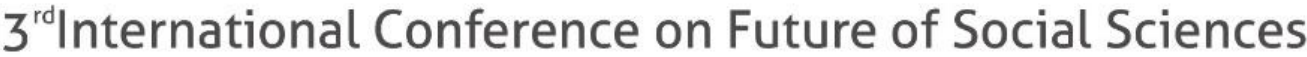

\section{5 - 7 March 2021}

Table 2. Confirmative factor analysis and reliability analysis

\begin{tabular}{|c|c|c|c|c|c|c|}
\hline Variable & Measured vaviable & $\begin{array}{l}\text { Loadin } \\
\mathrm{g}\end{array}$ & $\begin{array}{l}\text { Measurem } \\
\text { ent error } \\
\text { dispersion }\end{array}$ & $\mathrm{CR}$ & $\begin{array}{c}\mathrm{AV} \\
\mathrm{E}\end{array}$ & $\begin{array}{l}\text { Cronbach's } \\
\text { alpha }\end{array}$ \\
\hline \multirow{5}{*}{$\begin{array}{l}\text { Emotional } \\
\text { Attachment }\end{array}$} & $\begin{array}{l}\text { Volunteering at this residential child care center is } \\
\text { a pure delight }\end{array}$ & 0.589 & 0.267 & \multirow{5}{*}{$\begin{array}{l}0.8 \\
36\end{array}$} & \multirow{5}{*}{$\begin{array}{c}0.50 \\
8\end{array}$} & \multirow{5}{*}{0.691} \\
\hline & $\begin{array}{l}\text { Volunteering at this residential child care center } \\
\text { reminds me of beautiful experiences and memories. }\end{array}$ & 0.530 & 0.279 & & & \\
\hline & $\begin{array}{l}\text { If I were describing myself, volunteering at this } \\
\text { residential child care center would likely be } \\
\text { something that I would mention. }\end{array}$ & 0.449 & 0.352 & & & \\
\hline & $\begin{array}{l}\text { If someone praised volunteering at this residential } \\
\text { child care center, I would feel somewhat praised } \\
\text { myself. }\end{array}$ & 0.580 & 0.322 & & & \\
\hline & $\begin{array}{l}\text { People who know me might sometimes think about } \\
\text { me volunteering at this residential child care } \\
\text { center when they think of me. }\end{array}$ & 0.633 & 0.300 & & & \\
\hline \multirow{3}{*}{$\begin{array}{l}\text { Revisit } \\
\text { Intention }\end{array}$} & $\begin{array}{l}\text { I will keep visiting Cambodia for volunteer tourism } \\
\text { in the future }\end{array}$ & 0.815 & 0.182 & \multirow{3}{*}{$\begin{array}{l}0.9 \\
05\end{array}$} & \multirow{3}{*}{$\begin{array}{c}0.76 \\
1\end{array}$} & \multirow{3}{*}{0.835} \\
\hline & $\begin{array}{l}\text { I am more likely to visit Cambodia for volunteer } \\
\text { tourism next time }\end{array}$ & 0.765 & 0.225 & & & \\
\hline & $\begin{array}{l}\text { I will revisit Cambodia for volunteer tourism in the } \\
\text { future. }\end{array}$ & 0.792 & 0.182 & & & \\
\hline \multirow{4}{*}{ Wellbeing } & $\begin{array}{l}\text { Volunteering at this residential child care center } \\
\text { met my overall well-being needs. }\end{array}$ & 0.375 & 0.303 & \multirow{4}{*}{$\begin{array}{l}0.8 \\
34\end{array}$} & \multirow{4}{*}{$\begin{array}{c}0.56 \\
7\end{array}$} & \multirow{4}{*}{0.677} \\
\hline & $\begin{array}{l}\text { Volunteering at this residential child care center } \\
\text { played a very important role in my social well- } \\
\text { being. }\end{array}$ & 0.647 & 0.248 & & & \\
\hline & $\begin{array}{l}\text { Volunteering at this residential child care center } \\
\text { played an important role in my tourism well-being. }\end{array}$ & 0.682 & 0.321 & & & \\
\hline & $\begin{array}{l}\text { Volunteering at this residential child care center } \\
\text { played an important role in enhancing my quality of } \\
\text { life. }\end{array}$ & 0.688 & 0.270 & & & \\
\hline \multirow{4}{*}{$\begin{array}{l}\text { Donation } \\
\text { Intention }\end{array}$} & $\begin{array}{l}\text { I am likely donate something to the residential } \\
\text { child care center. }\end{array}$ & 0.836 & 0.151 & \multirow{4}{*}{$\begin{array}{c}0.9 \\
10\end{array}$} & \multirow{4}{*}{$\begin{array}{c}0.72 \\
1\end{array}$} & \multirow{4}{*}{0.835} \\
\hline & $\begin{array}{l}\text { I am willing to donate to the residential child care } \\
\text { center. }\end{array}$ & 0.780 & 0.165 & & & \\
\hline & $\begin{array}{l}\text { I will definitely donate to the residential child } \\
\text { care center. }\end{array}$ & 0.898 & 0.122 & & & \\
\hline & $\begin{array}{l}\text { I encourage friends and relatives to donate to the } \\
\text { residential child care center. }\end{array}$ & 0.546 & 0.493 & & & \\
\hline
\end{tabular}




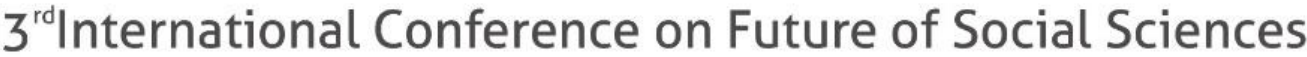

\section{5 - 7 March 2021}

BERLIN, GERMANY

Table3 Correlation coefficient and discriminant validity between construct concepts

\begin{tabular}{ccccc}
\hline & $\begin{array}{c}\text { Emotional } \\
\text { Attachment }\end{array}$ & Wellbeing & Revisit Intention & Donation Intention \\
\hline Emotional & 0.713 & & & \\
Attachment & $0.564^{* * *}$ & 0.753 & & \\
Wellbeing & $0.571^{* * *}$ & $0.617^{* * *}$ & 0.872 & \\
Revisit Intention & $0.510^{* * *}$ & $0.523^{* * *}$ & $0.461^{* * *}$ & 0.849 \\
Donation Intention & & & & \\
\hline
\end{tabular}

\subsection{Structural Model}

Structural model is used to verify the relationship among the latent construct between emotional attachment, well-being, revisit intention and donation intention used in this stud, the result of this study's structure model verification among concept are as fallows.

The structural model substantially fits the data, as accepted by the goodness-of-fit statistics $\mathrm{CMIN}=195.455, \mathrm{DF}=99, \mathrm{CMIN} / \mathrm{DF}=1.974, \mathrm{p}<.001, \mathrm{CFI}=.91, \mathrm{IFI}=0.912, \mathrm{TLI}=0.912$, AGFI $=0.841$, GFI $=0.885$, RMSEA $=.075$. IFI, TLI, AGFI, CFI and GFI are higher than RMSEA were judged to be below 0.08 with RMSEA $=.075$. it is considered appropriate $(\mathrm{Hu}$ and Bentler. 1999). The goodness-of-fit indices analyzed in present study can be regarded as an appropriate model to the goodness-of-fit of the model is definitely acceptable compared with the covariance structure analysis evaluation criteria.

Table 3: Hypothesis 1 emotional attachment to revisit intention was supported $(\beta=0.432$; $\mathrm{p}<0.01)$. Hypothesis 2 emotional attachment to donation intention $(\beta=0.106, p<0.575)$, thus the hypothesis 2 was not supported. Hypothesis 3 from emotional attachment to well-being was supported $(\beta=0.787, \mathrm{p}<0.001)$. Hypothesis 4 well-being to revisit intention was supported $(\beta=0.441, p<0.010)$. Hypothesis 5 well-being to donation intention was supported $(\beta=0.559$, $\mathrm{p}<0.004)$.

To summary, hypothesis 1 , hypothesis 3 , hypothesis 4 , hypothesis 5 were supported, but hypothesis 2 was not supported.

Table 4:

\begin{tabular}{|c|c|c|c|c|c|c|c|c|}
\hline & Items & & B & S.E. & C.R. & $\mathrm{P}$ & Beta & SMC \\
\hline Attachment & $--->$ & Well-being & 0.928 & 0.161 & 5.782 & $<0.001$ & 0.787 & 0.620 \\
\hline Attachment & $--->$ & \multirow[b]{2}{*}{ Revisit } & 0.577 & 0.235 & 2.456 & 0.014 & 0.432 & \multirow[b]{2}{*}{0.682} \\
\hline Wellbeing & $--->$ & & 0.5 & 0.193 & 2.584 & 0.010 & 0.441 & \\
\hline Attachment & $--->$ & & 0.169 & 0.301 & 0.561 & 0.575 & 0.106 & \multirow{2}{*}{0.417} \\
\hline Wellbeing & & & 0.753 & 0.264 & 2.85 & 0.004 & 0.559 & \\
\hline
\end{tabular}




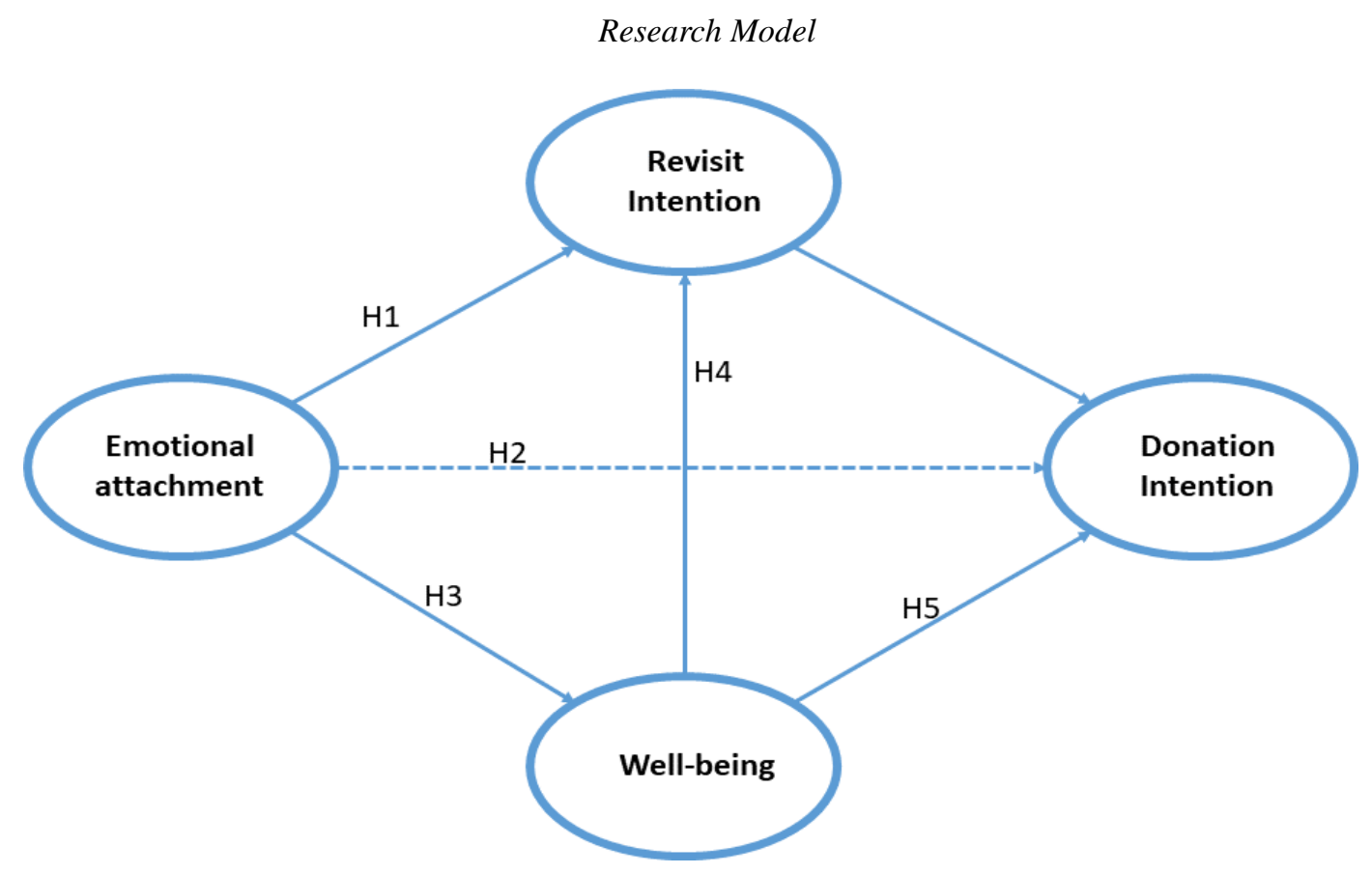

\section{Conclusion}

\subsection{Discussion}

This study assessed emotional attachment and well-being in a volunteer tourism context, and also proved significant to volunteer tourist's behavioral intention in residential child care centers. The result of SEM shows that in volunteer tourism context, emotional attachment and well-being roles, they offer important factors by determining the influence to volunteer tourists' behavioral intention, such as revisit intention and donation intention. This study confirms with previous studies that regarding emotional attachment was engaged to volunteer tourism in orphanages (Guiney, 2018), and well-being also have inter-relation to tourism (Smith \& Diekmann, 2017). Notably, emotional attachment and well-being effect to revisit intention and donation intention. This finding can be a new revelation to volunteer tourists themselves, and also market researchers, residential child care staffs, and volunteering agencies, in to pay more attention to emotional attachment and well-being. Many previous studies revealed that altruism and personal development are motivations for volunteer tourism. (Tomazos \& Butler,2008, Han et all. 2019; Brown, 2005; Chen \& Chen, 2011; Coghlan \& Weiler, 2018; Pan, 2017; Wearing, 2001). However, emotional attachment of volunteers with children in residential child care centers, also can lead volunteer staff to feel more intimacy and want to do or provide something for the children and remaining staffs. Well-being of volunteers also can attract certain volunteers wanting to visit residential child care centers so as to provide something for the children, because they feel satisfaction with their own life.

The result of this study also suggest that in volunteer tourism, that attachment can increase a volunteer's satisfaction and experience by looking at the result of their behavioral intention. In 
addition, well-being or life satisfaction of volunteers can provide economic support (eg. donation) and a feeling of intimacy to the children and staff (eg. revisit residential child care center). In other words, volunteers who are more likely to engage his/herself in residential child care centers may perceive high level of revisit and donation. This study supports prior finding that intimacy can be the reason that people do volunteer services (Conran, 2011). Furthermore, it is also supports a (Smith and Diekmann, 2017) study that was done, which revealed that well-being can be derived through tourism experiences. Additionally, emotional attachment has been found to be positively engaged with well-being, which means that the emotional attachment of volunteer tourists impacts their well-being concept during the they are in volunteer service. Volunteer tourists feel emotionally happy which play an important role to enhance volunteer's quality of life. Unfortunately, this emotional attachment of volunteer tourists also has an indirect effect to donation intention, but uses well-being as role model to connect both party (emotional attachment and donation intention). More frequently over the years, volunteer tourists who volunteer in residential child care centers, are volunteers who are highly involved in emotional attachment, thus the more common, to donate to the residential child care centers.

\subsection{Theoretical Implication}

The discoveries made from this study added a more valuable perception to present literature in volunteer tourism research. Firstly, by engaging the attachment theory and well-being perspective, the study widely opens the findings of a previous study in the context of volunteer tourism, by adding feature of emotional attachment. The present study highlights the expansion and validation of emotional attachment and thus sheds light on theoretical knowledge based on the formation of volunteer tourism context. Principally, this study pays attention to the concept that the well-being that role as moderated communication environment in volunteer tourism literature. Plenty of studies in volunteer tourism literature, have focused on attachment such as commitment, and satisfaction (Rempel, Ross, \& Holmes, 2001; Spake, Beatty, Brockman, \& Crutchfield, 2003; Thomson, 2006; Thomson, MacInnis, \& Park, 2005), consumer defections (Liljander \& Strandvik, 1995), disposal choice (Walker, 2006), evaluations of brand extensions (Fedorikhin, Park, \& Thomson, 2008), brand loyalty (Thomson, MacInnis, \& Park, 2005), and (negatively) to unethical behavior (Schmalz \& Orth, 2012). Given a vital role of attachment by improving relationships among volunteer in volunteer tourism (Hustinx \& Handy, 2009). The conceptual model proposed in present study may connect notable studies gap by giving comprehensive understanding about volunteer tourism in residential child care center.

Secondly, the research model creates three key theoretical perspectives such as emotional attachment, well-being and volunteer's behavioral intention. Particularly, adopting attachment theory, present study extends the literature in volunteer tourism practice by connecting the attachment theory to well-being concept. In previous study has confirmed that emotional attachment has relationship with customer loyalty and customers' satisfaction (Levy \& Hino, 2016). This study also confirmed with previous study that emotional attachment is an antecedent customer's behavioral intention (Loureiro, 2014), and well-being is also precursor of customer's behavioral intention (Kim, Lee \& Preis, 2020).

Thirdly, in present study, we find that emotional attachment is directly effect to revisit intention, however, it has indirect effect to donation intention. This finding propose emotional attachment and well-being in an individual form beneficial understanding future predicting of volunteer tourists' behaviors. Volunteer tourists are more likely to be satisfied their volunteer activities and intend to revisit and donate to the place they have memories of volunteering when they involve themselves in emotional attachment and well-being concept. Therefore, volunteer tourist who 
imply themselves in behavioral intention are likely to be influenced by emotional attachment and well-being relationship.

\subsection{Managerial Implication}

The present study results provide several managerial implications in volunteer tourism context. First, the findings of this study suggest that emotional attachment should be contemplated it can considerably help managers, volunteer agencies, and stakeholders in volunteer tourism in residential child care to establish and continually operate sustainable volunteer tourism. Therefore, it is critical for volunteer tourism to connect between volunteer tourists and stakeholders smoothly. In most cases emotional attachment in volunteer tourism can contribute to develop the volunteer tourists' behavioral intention. Activities such as taking care of babies and playing with time is more likely to make volunteers and children grow a bond of intimacy. According to this, managers, volunteer agencies, and stakeholders should consider volunteer's feelings by paying more attention to their emotion, and making more chances to make them happy (eg. let them enjoy more time with children, letting them communicate with children face to face, and creating field trips.

\subsection{Limitation and Direction for Future Research}

In spite of the contribution of present studies that increase our understanding about emotional attachment in volunteer tourism, several limitations should be recognized before put in the result of this study. Even though this study is relevant for validating the proposed relationship, the result may only be practical to volunteer tourism studied in this research. To certify this finding, future studies should investigate the relationship of volunteer tourism motivation and emotional attachment and with the outcome of these two parties, should collect the sample from different background.

Secondly, a sample collection of this study collected only one residential child care center (NBIC), the results can be better or little bit change in case that data collection was collected from other residential child care centers in Cambodia and other countries from ASEAN nations.

\section{References}

1. Bowlby, J. (1969). 1982. Attachment and loss, 1.

2. Bowlby, J. (1969/1982). Attachment and loss: Vol. 1. Attachment (2nd ed.). New York: Basic Books. (Original edition 1969).

3. Mathers, K. (2011). Travel, humanitarianism, and becoming American in Africa. Springer.

4. Conran, M. (2011). They really love me! Intimacy in volunteer tourism. Annals of tourism research, 38(4), 1454-1473.

5. Guiney, T. (2018). "Hug- an- orphan vacations":"Love" and emotion in orphanage tourism. The Geographical Journal, 184(2), 125-137.

6. Cousins, J. A., Evans, J., \& Sadler, J. P. (2009). 'I've paid to observe lions, not map roads!'-An emotional journey with conservation volunteers in South Africa. Geoforum, 40(6), 1069-1080.

7. UNICEF. (2011). With the best intentions. . . a study of attitudes towards residential care in Cambodia. Phnom Penh, Cambodia: UNICEF Cambodia

8. Lo, Ada S., and Candy YS Lee. "Motivations and perceived value of volunteer tourists from Hong 
Kong." Tourism management 32.2 (2011): 326-334.

9. Wearing, S. (2001). Volunteer tourism: Experiences that make a difference. Cabi.

10. Callanan, M., \& Thomas, S. (2005). Volunteer tourism. Niche tourism, 183-200.

11. Guiney, T., \& Mostafanezhad, M. (2015). The political economy of orphanage tourism in Cambodia. Tourist Studies, 15(2), 132-155.

12. Koo, G. Y., \& Hardin, R. (2008). Difference in Interrelationship between Spectators' Motives and Behavioral Intentions Based on Emotional Attachment. Sport Marketing Quarterly, 17(1).

13. Levy, S., \& Hino, H. (2016). Emotional brand attachment: a factor in customer-bank relationships. International Journal of Bank Marketing.

14. Thomson, M., MacInnis, D. J., \& Whan Park, C. (2005). The ties that bind: Measuring the strength of consumers' emotional attachments to brands. Journal of consumer psychology, 15(1), 77-91

15. Phillips, D. M., \& Baumgartner, H. (2002). The role of consumption emotions in the satisfaction response. Journal of Consumer psychology, 12(3), 243-252.

16. Pham, M. T., Cohen, J. B., Pracejus, J. W., \& Hughes, G. D. (2001). Affect monitoring and the primacy of feelings in judgment. Journal of consumer research, 28(2), 167-188

17. Yu, Y. T., \& Dean, A. (2001). The contribution of emotional satisfaction to consumer loyalty. International journal of service industry management.

18. Bloemer, J., \& De Ruyter, K. (1999). Customer loyalty in high and low involvement service settings: the moderating impact of positive emotions. Journal of marketing management, 15(4), 315-330.

19. Ladhari, R. (2007). The effect of consumption emotions on satisfaction and word- of- mouth communications. Psychology \& Marketing, 24(12), 1085-1108.

20. Wei, S., \& Milman, A. (2002). The impact of participation in activities while on vacation on seniors' psychological well-being: a path model application. Journal of Hospitality \& Tourism Research, 26(2), 175-185.

21. Kim, D., Park, C., Kim, H., \& Kim, J. (2019). Determinants and outcomes of volunteer satisfaction in mega sports events. Sustainability, 11(7), 1859.

22. Park, C. W., \& MacInnis, D. J. (2006). What's in and what's out: Questions on the boundaries of the attitude construct. Journal of consumer Research, 33(1), 16-18.

23. Fornell, C., \& Larcker, D. F. (1981). Evaluating structural equation models with unobservable variables and measurement error. Journal of marketing research, 18(1), 39-50.

24. Vlachos, P. A., Theotokis, A., Pramatari, K., \& Vrechopoulos, A. (2010). Consumer- retailer emotional attachment. European Journal of Marketing.

25. Rempel, J. K., Ross, M., \& Holmes, J. G. (2001). Trust and communicated attributions in close relationships. Journal of personality and social psychology, 81(1), 57.

26. Spake, D. F., Beatty, S. E., Brockman, B. K., \& Crutchfield, T. N. (2003). Consumer comfort in service relationships: Measurement and importance. Journal of Service Research, 5(4), 316-332.

27. Thomson, M. (2006). Human brands: Investigating antecedents to consumers' strong attachments to celebrities. Journal of marketing, 70(3), 104-119.

28. Thomson, M., MacInnis, D. J., \& Whan Park, C. (2005). The ties that bind: Measuring the strength of consumers' emotional attachments to brands. Journal of consumer psychology, 15(1), 77-91.

29. Ladhari, R., Massa, E., \& Skandrani, H. (2020). YouTube vloggers' popularity and influence: The roles of homophily, emotional attachment, and expertise. Journal of Retailing and Consumer Services, 54, 102027. 
30. Freud, A., \& Dann, S. (1951). An experiment in group upbringing. The psychoanalytic study of the child, 6(1), 127-168.

31. Rutter, M., \& Maughan, B. (1997). Psychosocial adversities in childhood and adult psychopathology. Journal of Personality Disorders, 11(1), 4-18.

32. Wolff, P. H., \& Fesseha, G. (1998). The orphans of Eritrea: Are orphanages part of the problem or part of the solution?. American Journal of Psychiatry, 155(10), 1319-1324.

33. Carpenter, K. (2015). Childhood studies and orphanage tourism in Cambodia. Annals of Tourism Research, 55, 15-27

34. Clark, P. G. (1996). Communication between provider and patient: Values, biography, and empowerment in clinical practice. Ageing \& Society, 16(6), 747-774.

35. Nay, R. (1998). Contradictions between perceptions and practices of caring in long-term care of elderly people. Journal of clinical nursing, 7(5), 401-408.

36. KELLER, V., \& BAKER, L. (2000). Communicate with care. $R N, 63(1), 32-32$.

37. Burgio, L. D., Stevens, A., Burgio, K. L., Roth, D. L., Paul, P., \& Gerstle, J. (2002). Teaching and maintaining behavior management skills in the nursing home. The Gerontologist, 42(4), 487-496

38. Brannon, D., Smyer, M. A., \& Cohn, M. D. (1992). Strategies for improving nursing home care: a research roundtable. The Journal of Long Term Care Administration, 20(4), 18-20.

39. Maas, M., Buckwalter, K. C., Swanson, E. A., \& Mobily, P. R. (1994). Training key to job satisfaction. The Journal of long term care administration, 22(1), 23.

40. Caris- Verhallen, W. M., Kerkstra, A., \& Bensing, J. M. (1997). The role of communications in nursing care for elderly people: a review of the literature. Journal of advanced nursing, 25(5), 915-933.

41. Lee, Y. S., \& Park, A. J. (2019). Structural Relationship Between Quality of Medical Service, Patients' Emotional Attachment, Customer Satisfaction, and the Customer Behavioral Intention of Small and Medium Hospitals-Mediating Effect of Emotional Attachment and Customer Satisfaction. The Korean Journal of Health Service Management, 13(2), 27-38.

42. Shin, S. H., Rhee, K. G., \& Kim, C. T. (2016). The Mediation Effects of Emotional Attachment and Patient Satisfaction in Outpatients Choice of Small-and Medium-sized Hospitals. Korea Journal of Business Administration, 29(12), 1849-1869.

43. Blau, G., \& Holladay, B. E. (2006). Testing the discriminant validity of a four- dimensional occupational commitment measure. Journal of Occupational and Organizational Psychology, 79(4), 691-704

44. Lord, J. G. (1981). Philanthropy and marketing: New strategies for fund raising. Third Sector Pr.

45. Burgoyne, C. B., Young, B., \& Walker, C. M. (2005). Deciding to give to charity: A focus group study in the context of the household economy. Journal of Community \& Applied Social Psychology, 15(5), 383-405.

46. Lee, Y. K., \& Chang, C. T. (2007). Who gives what to charity? Characteristics affecting donation behavior. Social Behavior and Personality: an international journal, 35(9), 1173-1180.

47. Sutton, S. (1994). The past predicts the future: Interpreting behavior-behavior relationships in social psychological models of health behavior.

48. Bozionelos, G., \& Bennett, P. (1999). The theory of planned behaviour as predictor of exercise: The moderating influence of beliefs and personality variables. Journal of health psychology, 4(4), 517-529

49. Wan, J., Lu, Y., Wang, B., \& Zhao, L. (2017). How attachment influences users' willingness to donate to content creators in social media: A socio-technical systems perspective. Information \& Management, 54(7), 837-850 
50. Diener, E., Lucas, R. E., \& Oishi, S. (2002). Subjective well-being: The science of happiness and life satisfaction. Handbook of positive psychology, 2, 63-73.

51. Thoits, P. A., \& Hewitt, L. N. (2001). Volunteer work and well-being. Journal of health and social behavior, 115-131.

52. Felce, D., \& Perry, J. (1995). Quality of life: Its definition and measurement. Research in developmental disabilities, 16(1), 51-74.

53. Ryff, C. D. (1989). Happiness is everything, or is it? Explorations on the meaning of psychological well-being. Journal of personality and social psychology, 57(6), 1069.

54. Baker, D. A., \& Crompton, J. L. (2000). Quality, satisfaction and behavioral intentions. Annals of tourism research, 27(3), 785-804.

55. Raza, M. A., Siddiquei, A. N., Awan, H. M., \& Bukhari, K. (2012). Relationship between service quality, perceived value, satisfaction and revisit intention in hotel industry. Interdisciplinary journal of contemporary research in business, 4(8), 788-805.

56. Pratminingsih, S. A., Rudatin, C. L., \& Rimenta, T. (2014). Roles of motivation and destination image in predicting tourist revisit intention: A case of Bandung-Indonesia. International Journal of Innovation, Management and Technology, 5(1), 19.

57. Ferreira, M. R., Proença, J. F., \& Rocha, M. (2016). Do occasional volunteers repeat their experience? Journal of Human Values, 22(2), 75-92.

58. Grzeskowiak, S., \& Sirgy, M. J. (2007). Consumer well-being (CWB): The effects of self-image congruence, brand-community belongingness, brand loyalty, and consumption recency. Applied research in Quality of Life, 2(4), 289-304

59. Jones, T. O., \& Sasser, W. E. (1995). Why satisfied customers defect. Harvard business review, $73(6), 88$.

60. Kim, I., Jeon, S. M., \& Hyun, S. S. (2012). Chain restaurant patrons' well- being perception and dining intentions. International Journal of Contemporary Hospitality Management

61. Dillard, J. P., \& Peck, E. (2000). Affect and persuasion: Emotional responses to public service announcements. Communication Research, 27(4), 461-495

62. Taylor, R., \& Shanka, T. (2008). Cause for event: not-for-profit marketing through participant sports events. Journal of Marketing Management, 24(9-10), 945-958.

63. Hendriks, M., \& Peelen, E. (2013). Personas in action: linking event participation motivation to charitable giving and sports. International Journal of Nonprofit and Voluntary Sector Marketing, 18(1), 60-72.

64. Gaier, S. (2005). Alumni satisfaction with their undergraduate academic experience and the impact on alumni giving and participation. International Journal of Educational Advancement, 5(4), 279-288.

65. Wang, L., \& Ashcraft, R. F. (2014). Organizational commitment and involvement: Explaining the decision to give to associations. Nonprofit and Voluntary Sector Quarterly, 43(2_suppl), 61S-83S

66. Fishbein, M. (1981). leek Ajzen (1975), Belief, Attitude, Intention, and Behavior: An Introduction to Theory and Research. Read-ing, MA: Addison-Wesley.

67. Baker, D. A., \& Crompton, J. L. (2000). Quality, satisfaction and behavioral intentions. Annals of tourism research, 27(3), 785-804

68. Kozak, M. (2001). Repeaters' behavior at two distinct destinations. Annals of tourism research, 28(3), 784-807.

69. Anderson, E. W., \& Sullivan, M. W. (1993). The antecedents and consequences of customer satisfaction for firms. Marketing science, 12(2), 125-143.

70. Hallowell, R. (1996). The relationships of customer satisfaction, customer loyalty, and 
profitability: an empirical study. International journal of service industry management.

71. LaBarbera, P. A., \& Mazursky, D. (1983). A longitudinal assessment of consumer satisfaction/dissatisfaction: the dynamic aspect of the cognitive process. Journal of marketing research, 20(4), 393-404.

72. Newman, J. W., \& Werbel, R. A. (1973). Multivariate analysis of brand loyalty for major household appliances. Journal of marketing research, 10(4), 404-409.

73. Rust, R. T., \& Zahorik, A. J. (1993). Customer satisfaction, customer retention, and market share. Journal of retailing, 69(2), 193-215.

74. Ross, G. F. (1993). Destination evaluation and vacation preferences. Annals of Tourism Research, 20(3), 477-489.

75. Sampol, C. J. (1996). Estimating the probability of return visits using a survey of tourist expenditure in the Balearic Islands. Tourism Economics, 2(4), 339-351.

76. Guiney, T. (2018). "Hug- an- orphan vacations":"Love" and emotion in orphanage tourism. The Geographical Journal, 184(2), 125-137.

77. Bornstein, E. (2012). Disquieting gifts: humanitarianism in New Delhi. Stanford University Press.

78. Schimmelpfennig, S. (2011). Hug-an-orphan vacations. Retrieved from http://goodintents.org/orphanages/hug-an-orphan-vacations-3 Accessed 15 November 2011.

79. Kim, I., Jeon, S. M., \& Hyun, S. S. (2012). Chain restaurant patrons' well- being perception and dining intentions. International Journal of Contemporary Hospitality Management.

80. Kim, I., \& Kim, J. J. (2017). Older adults' parasocial interaction formation process in the context of travel websites: The moderating role of parent-child geographic proximity. Tourism Management, 63, 399-416.

81. Zhang, H., Wu, Y., \& Buhalis, D. (2018). A model of perceived image, memorable tourism experiences and revisit intention. Journal of destination marketing \& management, 8, 326-336.

82. Ranganathan, S. K., \& Henley, W. H. (2008). Determinants of charitable donation intentions: a structural equation model. International journal of nonprofit and voluntary sector marketing, $13(1), 1-11$.

83. Nunnally, J. C., \& Bernstein, I. H. (1994). Psychometric theory 3rd edn. New York [etc].: McGrawHill.

84. Bagozzi, R. P., \& Yi, Y. (1988). On the evaluation of structural equation models. Journal of the academy of marketing science, 16(1), 74-94. 